\title{
TOWARDS SOCIAL CHANGE: SOUTH AFRICAN UNIVERSITY STUDENTS AS SOCIAL ENTREPRENEURS
}

\author{
B. Urban* \\ e-mail: boris.urban@wits.ac.za
}

\author{
L. Kujinga* \\ e-mail: Ikujinga@wits.ac.za
}

${ }^{*}$ Graduate School of Business and Management

University of Witwatersrand

Johannesburg, South Africa

\section{ABSTRACT}

South Africa needs higher education to be allied with societal issues, so that a social consciousness is nurtured among university students who can then play a transformative role in combating social inequalities. Social entrepreneurship, as a social change movement, has undeniable application in South Africa where traditional government schemes are unable to satisfy the entire social deficit. Students provide a fertile ground from which seeds of social entrepreneurship can grow, as they possess the talent, interest, and energy to become the next generation of social and civic leaders. This study conducts empirical investigations into understanding the antecedents in the formation of social entrepreneurship intentions. Examining the antecedents of desirability and feasibility to set up a social enterprise is an important first step in fostering social entrepreneurs. The study results show, from a university student survey, that the intent to pursue a social venture is positively and significantly associated with perceptions of desirability and feasibility of the undertaking. Implications for policy-makers relate to recognising that societal improvements can only come about through changes in individual actions and behaviours that are influenced by perceptions. Additionally, an opportunity exists for curriculum designers to develop skill-building exercises and activities that target the antecedents of social entrepreneurship intentions.

Keywords: Social entrepreneurship, intentions, students, South Africa

\section{INTRODUCTION}

Worldwide researchers and practitioners are advocating social change through social enterprises as a way to a more sustainable and fair society (Harding 2007, 73; Urban 2015, 163). Social entrepreneurship has captured the attention of leaders in different types of organisations as an innovative way to integrate economic activities into providing solutions for social problems (Porter and Kramer 2011, 1). Social entrepreneurship is increasingly 
appreciated as an attractive option under shifting market conditions and can be viewed as a process that catalyses social change (Mair and Marti 2006, 36). Social entrepreneurship is seen as a means to address social challenges within societies, which may manifest through philanthropic efforts, not-for-profit (NPOs), non-governmental organisations (NGOs), and organisational social initiatives (Dees and Economy 2001). Resonating with concepts such as the 'Third Way' and 'compassionate conservatism', social entrepreneurship's vision of congruence between private sector programmes and public sector principles is increasingly accepted as an alternative that expresses a captivating language of pragmatism, collaboration, and hope (Cho 2006, 34).

Social entrepreneurship has direct relevance to education in South Africa, where its transformative role in reducing severe inequalities has been recognised insofar South Africa needs 'higher education to be more closely aligned with societal issues, which can nurture social consciousness among privileged university graduates' (Walker 2015, 282). Social entrepreneurship has undeniable application in South Africa where traditional government initiatives are unable to satisfy the entire social deficit, and where the survival of many NGOs and social enterprises is at stake. These challenges are exacerbated by a social context characterized characterised by massive inequalities in education, housing, the HIV and Aids pandemic, and high unemployment and poverty rates (Rwigema, Urban and Venter 2010). Subsequently, researching social entrepreneurship is particularly relevant in the present South African socio-economic milieu, as it offers the promise of empowering marginalised segments of the population, such as the student youth (Venter 2014; Urban 2015).

South African university students, and in particular black youth, form a particularly important social category for analysis, as much emphasis is placed on youth transforming the country’s socio-economic future (Seekings 2008; Venter 2014). At the same it is also important to acknowledge the agentive qualities embodied by youth and students (Diouf 2003; Urban and Pendame 2015; Walker 2015). Bandura (2001, 3) states 'to be an agent is to intentionally make things happen by one's own actions, where efficacy beliefs are the foundation of human agency’.

Social changes are reliant on upon human agency and change can only come about through changes in individual beliefs, attitudes and behaviours (Baker 2011). Students, as youth, provide a fertile ground from which seeds of social entrepreneurship can emerge. Students often possess the talent, interest, and energy to become the next generation of social and civic leaders (Harding and Cowling 2006). Entrepreneurship is conceptualised as the practical application of enterprising qualities and skills such as initiative, innovation, creativity, and risk-taking (Schurr 
and Newig 1997). By applying this conceptualisation of entrepreneurship to more fully reflect the notion of social change and youth, it has been suggested that the following be taken into consideration - 'young individuals developing and making full use of their own abilities, alone or in groups; young people defining their own problems, identifying solutions and finding resources to realize their vision; and, young people realizing their own potential and vision, growing in confidence and taking active roles in their own communities' (Chigunta 2002, 2). These qualities resonate with social entrepreneurs, who by definition, are tackling social problems caused by shortcomings in existing markets and social welfare systems and aim to create systemic changes and sustainable improvements (Seelos and Mair 2005). Social entrepreneurs engage in a process of 'continuous innovation, adaptation, and learning; acting boldly without being limited by resources currently in hand and exhibit heightened accountability to the constituencies served and for the outcomes created' (Dees and Economy 2001, 2).

Recognising the importance of social entrepreneurship in South Africa, this study draws on a sample of students at public universities in South Africa to examine social entrepreneurship intentions (SEIs). The intent to pursue a social opportunity is based on the perceived desirability and feasibility of the undertaking. The core antecedents of intentions are perceptions of desirability and feasibility of entrepreneurial action (Mair and Noboa 2003). Desirability refers to whether an individual is attracted by the social opportunity, while perceived feasibility as the degree with which individuals believe in their own ability to create a social venture (Mair and Noboa 2006). By linking two seemingly disparate literatures (higher education and SEIs), this study aligns these topics and investigates the relationship between the antecedents of feasibility and desirability and SEI amongst university students, in an under-researched South African context.

Much of the current academic discussion around the nature of social entrepreneurship, higher education and intentions is occurring in United States based upon understandings, experiences, and evidence from the developed world. This anomaly is important considering the general absence of 'African epistemologies in formal education in Africa' (Fataar and Subreenduth 2015, 106), and where most studies on social entrepreneurship are predominantly western in nature. Social entrepreneurship not only has direct relevance to South Africa but also other emerging nations such as India and China, where dramatic changes in attitude have taken place, and where individuals understand that they can and should shape their own futures (Dafuleya 2012). According to Baker (2011) what matters for social entrepreneurship is the sense amongst the general population that it is up to them to find solutions for the challenges 
they confront. Clearly, a need exists for empirical research examining SEIs in South Africa that can also contribute to wider understandings across the field. Moreover, across social entrepreneurship research, and particularly in relation to Africa, there remain few quantitative studies (Urban 2015).

This study contributes to the higher education literature by improving understanding of the antecedents in the formation of SEI, which is important when explaining the relationship between individuals’ perceptions, context, and intentions (Baierl, Grichnik, Sporrle and Welpe 2014; Schlaegel and Koenig 2014), which also involves the internal deliberation of personal values/beliefs while making social sense (Bhowmick 2011). Finally, the study has important implications for educators and policy makers who can influence the formation and development of SEI (Harding and Cowling 2006).

This first part of this article provides a literature overview underlying the constructs under investigation. The second part introduces the methodological design of the empirical work that is based on primary survey data. The third section part presents the results of the statistical analysis, while the final part discusses the findings and their implications for educators and further research.

\section{LITERATURE REVIEW}

\section{Social entrepreneurship and intentions}

A critical review of the literature shows several differences in how social entrepreneurship is conceptualised: the term social entrepreneurship is focused on process or behaviour, while the term social entrepreneur is focused on the founder of enterprise, and the term social enterprise is focused on the tangible outcome of social entrepreneurship (Mair and Marti 2006; Peredo and McLean 2006).

Furthermore, the academic literature on social entrepreneurship reveals a number of themes and domains, which include (Bacq and Janssen 2011; Rwigema, Urban and Venter 2010).

- Social entrepreneurship occurs in a vast array of economic, educational, welfare, and social activities, reflecting diverse initiatives and activities;

- Social entrepreneurship may be conceptualized in different contexts, which include the public sector, community, NPOs, NGOs and social action organizations;

- $\quad$ Social entrepreneurship incorporates the roles of innovativeness, proactiveness and risk taking which have been used in distinguishing social entrepreneurship from other forms 
of community work.

Several researchers have also adopted a behavioural approach when analysing social entrepreneurship by focusing attention on the individual founder (Baierl et al. 2014; Urban 2008). Across a wide range of different behaviours, behavioural intentions have been identified as the immediate accurate predictor of actual behaviour (Ajzen 1991). Intentionality is a state of mind directing a person's attention toward a specific goal in order to achieve something (Bird 1988). Intentions have been directed towards the entrepreneurship domain insofar intention energises, directs and sustains action toward entrepreneurial goals (Liñán, Nabi and Krueger 2012).

Research finds that intentions are the single best predictor of any planned behaviour, including entrepreneurship (Krueger 1993), where a strong association exists between entrepreneurial intentions and actual entrepreneurial behaviour has been reported (Krueger, Reilly and Carsrud 2000). Since the seminal articles by Ajzen (1991), Shapero and Sokol (1982), and Bird (1988), a large and still growing number of studies have focused on entrepreneurial intentions and several models have been used to explain and test entrepreneurial intentions. Some of these are briefly delineated.

Bird (1988) was one of the first authors to emphasise the importance of intentions when studying entrepreneurship. Her model suggests that intentions develop from both rational and intuitive thinking, which in turn are affected by the entrepreneur's social, political, and economic context, history, current personality, and abilities. Bird's (1988) model of entrepreneurial intentionality, modified and improved by Boyd and Vozikis (1994) also suggests that individual self-efficacy can explain the development of entrepreneurial intentions and the model specifies the conditions under which these intentions may be translated into action. Shapero and Sokol's (1982) entrepreneurial event model, (EEM) shows that intentions rely on the elements of perceived desirability, likelihood to act, and perceived feasibility. Based on the EEM model, evidence is convincing that perceived desirability and propensity to act explain well over half the variance in intentions toward entrepreneurship, with feasibility perceptions explaining the most variance (Shapero and Sokol 1982). Ajzen's (1991) theory of planned behaviour (TPB) model is a recognised theory, where intentions are explained by attitudes toward behaviour, subjective norms, and perception of behavioural control. The TPB model suggests that 'people intend to perform a specific behaviour if their personal assessments of the questioned behaviour are positive, if they think their important referents agree with it, and if they assume that the required resources and opportunities are available' (Ajzen 1991, 183). 
Extending the pioneering work by Krueger et al. (2000), who were the first to compare and integrate the extant theories of intentions, Schlaegel and Koenig (2014) recently metaanalytically tested and compared the TPB (Ajzen 1991) and the EEM models (Shapero and Sokol 1982). Their evidence suggests that a combination of the TPB with perceived desirability is most powerful in explaining and understanding entrepreneurial intentions. In other words, positive attitudes toward entrepreneurship will positively affect the personal attractiveness of starting one's own business as attitudes that are more favourable justify more favourable perceptions of desirability of the behaviours related to the goal of becoming an entrepreneur (Fitzsimmons and Douglas 2011; Schlaegel and Koenig 2014).

In essence, the theory on intentions is clear that the resolution to become a social entrepreneur is influenced by the perceptions of desirability and feasibility, where individuals must perceive themselves as both capable and psychologically equipped to function (Liñán, Rodriguez-Cohard and Rueda-Cantuche 2005; Mair and Noboa 2003). Consistent with such empirical evidence and by building on Mair and Noboa's (2003) model, hypotheses are formulated, where:

- H1: Perceptions of feasibility by students in higher education are positively related to social entrepreneurial intentions

- H2: Perceptions of desirability by students in higher education are positively related to social entrepreneurial intentions

For the purpose of the study, it is acknowledged that the actual process of how perceptions of feasibility and desirability of SEIs are formed is far more complex and that no single element can determine the outcome of this process. A number of factors are necessary, but no one is sufficient (Shapero and Sokol 1982). Additionally, it is also important to recognise that potential factors work in combination rather than as single predictors (Mair and Noboa 2003). Notwithstanding the complexity of SEIs and the reciprocal nature of relationships between the antecedents of feasibility and desirability, the study and subsequent data analyses are restricted to the number of factors and links as reflected in the hypotheses.

\section{METHODOLOGY}

This study follows the trend where researchers have focused on using quantitative research methods to establish the legitimacy of social entrepreneurship as an explicit domain of inquiry (Dacin, Dacin and Tracey et al. 2011; Urban 2015). A methodological survey based approach 
consistent with previous studies on social entrepreneurship and intention was used (Liñán and Chen 2009). Given the predominantly psychological nature of the constructs examined in this study, it was deemed useful to rely on university students as student samples represent a meaningful first step in exploring the psychological basis for behaviours (Audia, Locke and Smith 2000). Additionally, a student sample is likely to provide greater heterogeneity in SEI than using a sample of social entrepreneurs, since the homogeneity typical of samples restricted to individuals within 'productive-economic organizations' obstructs the assumption of generalizability beyond a very narrowly focused population (Greenberg 1987).

\section{Sampling and data collection}

The study draws on a sample of students at universities in South Africa (SA). SA's 26 public universities are distributed within all nine provinces of SA. Provinces which house the three main metropolitan centres, namely KwaZulu-Natal, Gauteng and the Western Cape, are home to the largest number of universities. Prominent public South African universities include the University of Johannesburg, University of Cape Town, University of KwaZulu-Natal, University of Pretoria, University of Stellenbosch, University of Witwatersrand, Rhodes University and the University of South Africa (Universities SA 2016).

The survey population consisted of 1200 students in the Faculties of Management and Commerce at three different prominent public universities in South Africa during the survey period (August-October 2015). To ensure sufficient variability and a high regional representativeness, data was drawn from the three largest provinces across South Africa. The rationale for selecting commerce and management students is that past research has found that the propensity of social entrepreneurial engagement to be more prevalent amongst management students than the rest of the general population (Urban and Pendame 2015).

As the objective of this article study was to investigate SEI and its antecedents, individuals who were either full or part-time social entrepreneurs or were starting a social enterprise at the time the survey was conducted were excluded from the survey. A written request was submitted to the relevant university officer to obtain necessary permission for students to participate and to administer the survey. Approval letters were obtained from the relevant officers at the universities where the ethics approval process required an offer of anonymity to respondents. The data collection phase was preceded by a pilot phase in August 2015, during which 25 respondents were requested to comment on the questionnaire, allowing refinement of the instrument. The first mailing resulted in a response of 153 students, and was followed by a second and third email request for filling out the on-line questionnaire, one week and three 
weeks later respectively. These efforts resulted in 40 additional responses. No patterns among undelivered surveys were noticed as undelivered surveys were distributed approximately evenly among different schools/faculties, resulting in 193 full questionnaires or a response rate of 16.5 per cent. Previous similar studies have reported response rates of 26 per cent (Urban 2015), and this response rate was deemed acceptable for online e-mail-solicited surveys of this nature (Cooper and Schindler 2011). Additionally, T-tests were conducted on the sample and no significant differences between early and late respondents in institutional location, age or gender were detected.

Characteristics of the sample indicate that more males (55\%) than females (45\%) were sampled and majority of the respondents (66\%) were in the age group 25-31 years old, 24 per cent were between 18-24 years old, while 9 per cent were 32-38 years old. The majority of the respondents have family members who were either currently entrepreneurs or had been entrepreneurs (64 per cent).

\section{The research instrument}

The research survey design was a self-reporting closed-ended questionnaire consisting of three separate sections. Care was taken to ensure clarity in terminology and to ensure that the items of the questionnaire corresponded to each of the hypotheses. Following the literature review, suitable measures for the purpose of this study were identified where theoretical and empirical support for each construct was evident.

\section{SEI}

SEI was operationalised as an attempt at new social enterprise activity or new enterprise creation, with social or community goals as its base and where the profit is invested in the activity or venture rather than returned to investors (Harding and Cowling 2006). Scale items were sourced from previous research (Liñán 2008; Mair and Noboa 2006) and slightly modified to address social entrepreneurship in accordance with the aim of the study (nine items were used to measure SEI and included questions such as: 'I will make every effort to start and run my own social enterprise; I am determined to create a social entrepreneurial venture in the future; I have very seriously thought of starting a social enterprise in the future'. Following recommendations that the degree and intensity of individuals' entrepreneurial intent might be expected to vary from person to person, and to vary for the same person at different points in time depending on circumstances, individual entrepreneurial intent was assessed using a continuous five-point Likert-type scale, as opposed to a categorical, instrument (Urban 2015). 


\section{Perceived feasibility and desirability}

The measures for the antecedents were developed from past studies (Shapero and Sokol 1982; Mair and Noboa 2003). Desirability was operationalised in terms of 'whether an individual is attracted by the social opportunity and feasibility as to whether an individual feels capable of creating a social venture' (Mair and Noboa 2006). Perceived desirability was composed of three items - 'I would love it; I would be tense; I would be enthusiastic', and perceived feasibility had five items - 'It would be very easy; I would be certain of success; I would not be overworked; I know enough to start a social business; I am sure of myself'. All items were measured along a five-point Likert-type scale, ranging from 'mostly disagree' = (1) to 'mostly agree' $=(5)$ ', where respondents were required to indicate the extent of their agreement with each statement. In some instances, items were reverse coded in the scale analyses and the wording was adjusted to reflect a social entrepreneurship context. The questionnaire featured a 'counter-balanced' question order, and the respondents were requested to be honest in their responses while assuring completely anonymous (Cooper and Schindler 2011).

\section{Control variables}

A number of individual-level factors, which have been shown to influence students and entrepreneurial intentions (Nel and Neale-Shutte 2013; Urban and Pendame 2015) were accounted in the study, these include: Gender: Males have been found to be more likely to engage in entrepreneurship compared to females (Engle et al. 2010). Age: Generation Y is considered to be more likely to pursue and establish social enterprises (Herrington and Kew 2014). The average age group engaging in social entrepreneurship has been reported to be between 25 and 34 years of age, while the 18 to 24-year age group being least likely to engage in social entrepreneurship (Terjesen et al. 2012). Family background: Entrepreneurial parents and relatives are viewed as the perfect role models. The likelihood of engaging in entrepreneurship is higher when there is a history of entrepreneurship in the family (Urban 2008).

These control variables were coded as follows: Gender (dummy variables $1=$ male, $0=$ female), family background (dummy variables $1=$ yes, $0=$ no), age categories (18-24; 25-31; 32-38; 39-45; 45+).

\section{DATA ANALYSIS}

Initially the psychometric properties of the constructs were established. This was followed by 
a descriptive and correlational statistical analysis.

\section{Results}

\section{Reliability and validity of scales}

The reliability and validity of the measurement scales was assessed by means of exploratory factor analysis (EFA). EFA was performed using the principal axis factoring with Varimax rotation and Kaiser normalization. Kaiser-Meyer-Olkin Measure of Sampling Adequacy and Bartlett's Test of Sphericity results are shown for each construct in Table 1. The results indicate that significant $(\mathrm{p}<0.001)$ Chi-Squares were obtained across all the constructs.

Table 1: KMO and Bartlett's Test results for the study constructs

\begin{tabular}{|c|c|c|c|}
\hline \multicolumn{3}{|l|}{ Perceived desirability } & \\
\hline \multicolumn{2}{|c|}{ Kaiser-Meyer-Olkin Measure of Sampling Adequacy } & .500 & \\
\hline \multirow[t]{3}{*}{ Bartlett's Test of Sphericity } & Approx. Chi-Square & 117.733 & \\
\hline & df & 1 & \\
\hline & Sig. & .000 & \\
\hline \multicolumn{4}{|l|}{ Perceived feasibility } \\
\hline \multicolumn{3}{|c|}{ Kaiser-Meyer-Olkin Measure of Sampling Adequacy } & .719 \\
\hline \multirow[t]{3}{*}{ Bartlett's Test of Sphericity } & \multicolumn{2}{|c|}{ Approx. Chi-Square } & 165.239 \\
\hline & \multicolumn{2}{|l|}{ df } & 10 \\
\hline & \multicolumn{2}{|l|}{ Sig. } & .000 \\
\hline \multicolumn{4}{|c|}{ Social entrepreneurship intentions (SEI) } \\
\hline \multicolumn{3}{|c|}{ Kaiser-Meyer-Olkin Measure of Sampling Adequacy } & .929 \\
\hline \multirow[t]{3}{*}{ Bartlett's Test of Sphericity } & \multicolumn{2}{|c|}{ Approx. Chi-Square } & 855.919 \\
\hline & \multicolumn{2}{|l|}{ df } & 36 \\
\hline & \multicolumn{2}{|l|}{ Sig. } & .000 \\
\hline
\end{tabular}

Table 2 shows the full rotated component matrix for the constructs, where six components were extracted. Table 3 shows the factor loadings, all having values $>.40$, as per the final six factor solution. EFA results indicated that all the items on each scale loaded highly on their respective constructs except for the item 'I would be tense', which was removed from the perceived desirability scale construct since it had an anti-image correlation of 0.127 (less than 0.4 , the cut off). Thus, the desirability scale ended up with two items. The reliability of the scales was tested using Cronbach’s alpha (Cooper and Schindler 2011) for internal consistency and satisfactory results were obtained $(>.70)$ - see Table 3. Comparisons of means tests were conducted to evaluate the effects of single control variables on SEI in isolation to other control variables, with no significant results detected. Similarly, individual one-way ANOVA tests did not find any statistical differences in SEI between any of the control variables expect for gender where 
the SEI mean was higher for female respondents (mean = 3.402) compared to that of male respondents $($ mean $=3.097)$, but was not statistically significant $(p=0.069)$. Following the comparison of means test, control variables were not factored into the further analysis.

Table 4 reports the means, standard deviations, and Pearson correlations. In terms of descriptive, respondents showed most agreement with the perceived desirability construct $($ mean $=3.92$ out of 5$)$, followed by SEI $($ mean $=3.42)$, and perceived feasibility $($ mean $=2.93)$. In terms of correlations, similar to other entrepreneurial intentions studies, a relatively moderate correlation between the antecedents of feasibility and desirability was observed (Liñán et al. 2005). Cooper and Schindler (2011) suggest correlations above 0.4 are moderate to strong and should be large enough to be statistically significant at $\mathrm{p}=0.05$ or below. Both antecedents of feasibility $(r=0.365 ; \mathrm{p}<0.05)$ and desirability $(\mathrm{r}=0.331 ; \mathrm{p}<0.05)$ were significantly and positively correlated with SEI, providing support for $\mathrm{H} 1$ and $\mathrm{H} 2$.

Table 2: Rotated component matrix for constructs

\begin{tabular}{|c|c|c|c|c|c|c|}
\hline \multirow{2}{*}{ Rotated Component Matrix ${ }^{a}$} & \multicolumn{6}{|c|}{ Component } \\
\hline & 1 & 2 & 3 & 4 & 5 & 6 \\
\hline $\begin{array}{l}\text { Social entrepreneurial intentions: I am determined to create } \\
\text { a social entrepreneurial venture in the future }\end{array}$ & .899 & -.013 & -.125 & .145 & .072 & .003 \\
\hline $\begin{array}{l}\text { Social entrepreneurial intentions: I have very seriously } \\
\text { thought of starting a social enterprise in the future }\end{array}$ & .872 & .021 & -.117 & -.027 & .107 & .012 \\
\hline $\begin{array}{l}\text { Social entrepreneurial intentions: I have a strong intention } \\
\text { to start a social enterprise in the future }\end{array}$ & .856 & -.006 & -.154 & .071 & .101 & .055 \\
\hline $\begin{array}{l}\text { Social entrepreneurial intentions: My professional goal is to } \\
\text { be a social entrepreneur }\end{array}$ & .849 & .088 & .055 & -.046 & -.086 & -.008 \\
\hline $\begin{array}{l}\text { Social entrepreneurial intentions: I will make every effort to } \\
\text { start and run my own social enterprise }\end{array}$ & .843 & .098 & .027 & .070 & -.045 & -.049 \\
\hline $\begin{array}{l}\text { Social entrepreneurial intentions: I do not have doubts } \\
\text { about ever starting my own social enterprise in the future }\end{array}$ & .827 & .039 & -.100 & -.001 & .069 & .076 \\
\hline $\begin{array}{l}\text { Social entrepreneurial intentions: My qualification has } \\
\text { contributed positively towards my interest in starting a } \\
\text { social enterprise }\end{array}$ & .756 & .061 & -.018 & -.055 & .080 & .005 \\
\hline $\begin{array}{l}\text { Social entrepreneurial intentions: I am ready to do anything } \\
\text { to be a social entrepreneur }\end{array}$ & .686 & .013 & .177 & -.023 & -.192 & -.032 \\
\hline $\begin{array}{l}\text { Social entrepreneurial intentions: I had a strong intention to } \\
\text { start my own social enterprise before I started studying }\end{array}$ & .642 & .159 & .078 & -.054 & -.254 & .149 \\
\hline Desirability: I would love it & .015 & .007 & -.045 & -.021 & .913 & .012 \\
\hline Desirability: I would be enthusiastic & -.048 & .014 & -.065 & .006 & .854 & .028 \\
\hline Feasibility: I am sure of myself & .014 & .010 & -.029 & .130 & .549 & .501 \\
\hline Feasibility: It would be very easy & .073 & .081 & -.020 & -.068 & -.027 & .839 \\
\hline Feasibility: I know enough to start a social business & .076 & .110 & .030 & .095 & .198 & .758 \\
\hline Feasibility: I would not be overworked & -.042 & .288 & .108 & .081 & -.133 & .622 \\
\hline Feasibility: I would be certain of success & .000 & .044 & .191 & .009 & .482 & .547 \\
\hline
\end{tabular}

Extraction Method: Principal Component Analysis. Rotation Method: Varimax with Kaiser Normalization.

a. Rotation converged in 6 iterations. 
Table 3: Factor loadings, total variance explained and reliability results

\begin{tabular}{|c|c|c|c|c|}
\hline Construct & Items & Factor loading & $\begin{array}{l}\text { Total } \\
\text { variance } \\
\text { explained by } \\
\text { construct }\end{array}$ & $\begin{array}{l}\text { Cronbach's } \\
\text { Alpha }\end{array}$ \\
\hline \multirow[t]{2}{*}{ Desirability } & I would love it & 0.943 & \multirow[t]{2}{*}{89.01} & \multirow[t]{2}{*}{0.876} \\
\hline & I would be enthusiastic & 0.943 & & \\
\hline \multirow[t]{5}{*}{ Feasibility } & I know enough to start a social venture & 0.799 & \multirow[t]{5}{*}{50.49} & \multirow[t]{5}{*}{0.751} \\
\hline & It would be very easy & 0.750 & & \\
\hline & I would be certain of success & 0.739 & & \\
\hline & I am sure of myself & 0.684 & & \\
\hline & I would not be overworked & 0.557 & & \\
\hline \multirow{9}{*}{$\begin{array}{l}\text { Social } \\
\text { entrepreneur } \\
\text { intentions }\end{array}$} & $\begin{array}{l}\text { I am determined to create a social } \\
\text { entrepreneurial venture in the future }\end{array}$ & 0.902 & \multirow[t]{9}{*}{65.66} & \multirow[t]{9}{*}{0.932} \\
\hline & $\begin{array}{l}\text { I have very seriously thought of starting a } \\
\text { social venture in the future }\end{array}$ & 0.873 & & \\
\hline & $\begin{array}{l}\text { I have a strong intention to start a social } \\
\text { venture in the future }\end{array}$ & 0.860 & & \\
\hline & $\begin{array}{l}\text { My professional goal is to be an social } \\
\text { entrepreneur }\end{array}$ & 0.852 & & \\
\hline & $\begin{array}{l}\text { I will make every effort to start and run my } \\
\text { own social venture }\end{array}$ & 0.846 & & \\
\hline & $\begin{array}{l}\text { I do not have doubts about ever starting } \\
\text { my own social venture in the future }\end{array}$ & 0.832 & & \\
\hline & $\begin{array}{l}\text { My qualification has contributed positively } \\
\text { towards my interest in starting a social } \\
\text { venture }\end{array}$ & 0.759 & & \\
\hline & $\begin{array}{l}\text { I am ready to do anything to be an social } \\
\text { entrepreneur }\end{array}$ & 0.679 & & \\
\hline & $\begin{array}{l}\text { I had a strong intention to start my own } \\
\text { social venture before I started studying }\end{array}$ & 0.652 & & \\
\hline
\end{tabular}

Table 4: Descriptives and correlations

\begin{tabular}{|l|l|l|l|l|l|}
\hline & Mean & Std. Dev. & Feasibility & Desirability & SEI \\
\hline Feasibility & 2.937 & 0.728 & 1 & & \\
\hline Desirability & 3.921 & 1.150 & $.271^{* \star}$ & 1 & \\
\hline SEI & 3.427 & 0.875 & $.365^{\star}$ & $.331^{\star}$ & 1 \\
\hline
\end{tabular}

${ }^{*} \mathrm{p}<0.05 ;{ }^{* *} \mathrm{p}<0.01$

\section{DISCUSSION AND CONCLUSIONS}

This study joins an emerging stream of research on social entrepreneurship and connects it to the higher education context. By formulating social entrepreneurship specific hypotheses and generating insights on student intentions, this new area of study is expanded. Researching the antecedents of behavioural intentions to set up a social enterprise is an important first step towards an inclusive theory of social entrepreneurship (Mair and Noboa 2003).

When considering the overall paucity of research on social entrepreneurship in higher education, particularly in a non-western context, the study makes a modest contribution to the 
body of knowledge in an under-researched African context.

In terms of the study results, both hypotheses were supported where findings indicate a positive and significant accusation between perceived desirability, perceived feasibility and SEIs. These results affirm the notion that the intent to pursue a social opportunity and create a social venture is positively associated with perceived desirability and feasibility of the undertaking. The intention to perform a specific behaviour is mainly motivated by the desire to perform this behaviour and to achieve a specific goal. Desirability is goal-related and provides the motivational basis for an intended goal-directed behaviour. Feasibility, on the other hand, is affected by the person's perceived ability to perform the specific behaviour required for setting up the social venture and is related to self-efficacy beliefs (Urban 2015).

Connecting the study results with past studies highlights the positive and significant correlation of both feasibility and desirability with SEI. The concept of feasibility highlights the importance of an individual's perceptions of their ability to undertake and succeed in entrepreneurial behaviour. Perceived feasibility connects conceptually with self-efficacy, and is an important motivational construct that influences individual choices, goals, emotional reactions, effort, coping and persistence (Boyd and Vozikis 1994). Research findings show that increasing self-efficacy will enhance perceptions of feasibility to undertake a social venture (Urban 2015). Similarly, the intention to perform a specific behaviour is motivated by the desire to perform this behaviour and positive attitudes toward social entrepreneurship will positively affect the personal attractiveness of starting a social enterprise (Mair and Noboa 2003). Consequently, understanding the antecedents influencing SEI is essential in equipping individuals with the skills necessary to start social enterprises in order eradicate social problems in South Africa.

The results of the study also have contextual relevance where emerging economies provide a unique environment, which offers the ability to obtain new insights and to expand SE theory (Bruton, Ahlstrom and Obloj 2008; Urban 2015). The social enterprise sector across Sub-Saharan Africa is still highly influenced by local, international and bilateral political and economic decisions that often challenge the success of SE initiatives (Karanda and Toledano 2012). Despite the proliferation of SE in SA, the survival of many social enterprises and NGOs remains dubious. Research notes that legislation and policies created to empower previously disadvantaged groups through social enterprises has at best achieved mixed results in SA (Rwigema et al. 2010). Consequently, it is particularly important to stimulate SE in SA as it offers the promise of empowering marginalised segments of the population, where traditional government initiatives have failed (Rwigema et al. 2010). 
The study also yields methodological contributions when considering that concerns have been expressed as to whether imported instruments would stand up to cross-validation in nonwestern contexts (Urban 2008). In this study the reliability and validity of perceptions of feasibility and desirability and SEI was established. Based on factor analysis results construct validity was established which adds to the growing knowledge base and provides greater and clearer understanding of these antecedents of SEI in a higher education context. Furthermore, the study has demonstrated the usefulness of relying on higher education student samples, where past studies find that student respondents often possess the talent, interest, and energy to become the next generation of social entrepreneurs (Harding and Cowling 2006).

Several educational, practitioner and policy implications can be drawn from this study. While political initiatives and regulatory measures are essential to raise awareness about social changes, ultimately societal improvements can only come about through changes in individual actions and behaviours that are influenced by perceptions (Baker 2011). SE, in order to manifest into a change-orientated activity requires perceptions of feasibility and desirability to bring about social change. Many individuals in SA may have the desire to pursue SE but are not engaging because they are lacking in self-efficacy and requisite entrepreneurial skills, which are linked to feasibility and desirability of SEI (Urban 2015). Currently, in SA, the education system is not leading to positive perceptions of personal feasibility and desirability as far as entrepreneurship is concerned, which has a negative impact on the size of the country's pool of intentional entrepreneurs (Herrington and Kew 2014). This is disconcerting when considering that the entire entrepreneurial process unfolds because individuals have entrepreneurial intentions, act and are motivated to pursue opportunities (Shane and Venkataraman 2001).

A more restrained view would be that even though SE is a promising alternative for resolving specific social problems, it must be seen as a complement to, rather than a substitute for, processes of governance. Social entrepreneurs can approach the public sector as a potential partner rather than a competitor in the delivery of key services. Social entrepreneurs cannot afford to isolate themselves from other key actors, but must actively search for opportunities to cooperate with and actively support their partners (Cho 2006).

Higher educational and training institutions are well positioned to shape perceptions and aspirations of students (Urban and Pendame 2015). Consequently, increased exposure to SE and social entrepreneurs could help foster entrepreneurial skills and abilities and generally improve perceptions of feasibility and desirability. Educators can focus on making SE an attractive career choice by promoting the field. By improving SE perceptions and nurturing societal norms towards SE, an opportunity exists for curriculum designers to develop skill- 
building exercises and activities that target the antecedents of SEI, as demonstrated in this study. Research supports the notion of entrepreneurial development, where teaching and training increases levels of self-esteem and confidence of youths, leading to greater self-control over their lives in both social and economic spheres (Baker 2011).

In conclusion it is recommended that aspiring social entrepreneur practitioners and educators recognise the growing interest which is placed on the 'social economy', which is a way of incorporating economic activities into solving solutions for social needs and involving disadvantaged communities in the process of creating social value (Nicholls 2011). In fact, SE as actors in the social economy could pave the way to a more sustainable and fair society and could possibly serve as a post-capitalist alternative (Baker 2011).

The study is limited by its cross-sectional nature, where the dynamism of the perceptions of SEI is lost by studying them at a snapshot in time. A longitudinal approach would enhance additional understanding into the development of SEI over time including the changing role played by others factors not accounted for in this study, such as institutional and contextual factors. Lastly, the relationship between antecedents and SEI could be extended to include factors such as moral judgement and empathy, as per Mair and Noboa (2003), or African specific factors, such as Ubuntu.

\section{REFERENCES}

Ajzen, I. 1991. The theory of planned behaviour. Organizational Behavior and Human Decision Processes 50(2): 179-211.

Audia, P. G., E. A. Locke and K. G. Smith. 2000. The paradox of success: An archival and a laboratory study of strategic persistence following radical environmental change. Academy of Management Journal 43(5): 837-853.

Bacq, S. and F. Janssen. 2011. The multiple faces of social entrepreneurship: A review of definitional issues based on geographical and thematic criteria. Entrepreneurship and Regional Development 23(2): 373-403.

Baierl, R., D. Grichnik, M. Sporrle and I. M. Welpe. 2014. Antecedents of social entrepreneurial intentions: The role of an individual's general social appraisal. Journal of Social Entrepreneurship 5(2): 123-145.

Baker, M. J. 2011. Editorial - why ‘social business’? Social Business 1(1): 1-15.

Bandura, A. 2001. Social cognitive theory: an agentic perspective. Annual Review of Psychology 1(1): $1-36$.

Bhowmick, S. 2011. Social cause venturing as a distinct domain. Journal of Social Entrepreneurship 2(1): 80-99.

Bird, B. 1988. Implementing entrepreneurial ideas: The case for intention. The Academy of Management Review 13(3): 442-453.

Boyd, N. G. and G. S. Vozikis. 1994. The influence of self-efficacy on the development of entrepreneurial intentions and actions. Entrepreneurship Theory and Practice 18(1): 63-63.

Bruton, G. D., D. Ahlstrom and K. Obloj. 2008. Entrepreneurship in emerging economics: Where are we today and where the research should go in the future? Entrepreneurship Theory and Practice 
32(1): $1-14$.

Chigunta, F. 2002. Youth entrepreneurship: Meeting the key policy challenges. Wolfson College, Oxford University, England.

Cho, A. H. 2006. Politics, values and social entrepreneurship: A critical appraisal in social entrepreneurship, ed. Johanna Mair, Jeffrey Robinson and Kai Hockerts. Palgrave Macmillan, New York.

Cooper, D. R. and P. S. Schindler. 2011. Business research methods. 11th Edition. McGraw Hill International Edition, New York.

Dacin, M. T., P. A. Dacin and P. Tracey. 2011. Social entrepreneurship: A critique and future directions. Organization Science 22(5): 1203-1213.

Dafuleya, G. 2012. Enterprising in the face of death: Social entrepreneurship in African Burial Societies. Journal of Enterprising Culture 20(3): 357-378.

Dees, J. G. and P. Economy. 2001. Social entrepreneurship. Enterprising non-profits: A toolkit for social entrepreneurs. John Wiley \& Sons, New York.

Diouf, M. 2003. Engaging postcolonical cultures: African youth and public space. African Studies Review 46(2): 1-12.

Engle, R. L., N. Dimitriadi, J. V. Gavidia, C. Schlaegel, S. Delanoe, I. Alvarado, X. He, S. Buame and B. Wolff. 2010. Entrepreneurial intent: A twelve-country evaluation of Ajzen's model of planned behaviour. International Journal of Entrepreneurial Behavior and Research 16(1): 35-37.

Fataar, A. and S. Subreenduth. 2015. The search for ecologies of knowledge in the encounter with African empistemicide in South African education. South African Journal of Higher Education 29(2): 106-121.

Fitzsimmons, J. R. and E. J. Douglas. 2011. Interaction between feasibility and desirability in the formation of entrepreneurial intentions. Journal of Business Venturing 26(4): 431-440.

Greenberg, J. 1987. The college sophomore as a guinea pig: Setting the record straight. Academy of Management Review 12(1): 157-159.

Harding, R. 2007. Understanding social entrepreneurship. Industry and Higher Education 21(1): 73-84.

Harding, R. and M. Cowling. 2006. Points of view assessing the scale of the equity gap. Journal of Small Business and Enterprise Development 13(1): 115-132.

Herrington, M. and J. Kew. 2014. Global entrepreneurship monitor: South African Report. Twenty Years democracy. Centre for innovation and entrepreneurship: University of Cape Town, South Africa.

Karanda, C. and N. Toledano. 2012. Social entrepreneurship in South Africa: A different narrative for a different context. Social Enterprise Journal 8(3): 201-215.

Krueger, N. F. 1993. The impact of prior entrepreneurial exposure on perceptions of new venture feasibility and desirability. Entrepreneurship Theory and Practice 18(1): 5-21.

Krueger, N. F., M. D. Reilly and A. L. Carsrud. 2000. Competing models of EI. Journal of Business Venturing 15(5-6): 411-432.

Liñán, F. 2008. Skill and value perceptions: How do they affect entrepreneurial intentions? International Entrepreneurship and Management Journal 4(3): 257-272.

Liñán, F., G. Nabi and N. Krueger. 2012. British and Spanish entrepreneurial intentions: A comparative study. Revista de Economía Mundial 33(1): 73-103.

Liñán, F., J. C. Rodriguez-Cohard and J. M. Rueda-Cantuche. 2005. Factors affecting entrepreneurial intention levels. Paper presented at the 45th Congress of the European Regional Science Association, Amsterdam.

Liñán, F. and Y. Chen. 2009. Development and cross-cultural application of a specific instrument to measure entrepreneurial intentions. Entrepreneurship Theory and Practice 3(3): 593-617.

Mair, J. and E. Noboa. 2003. Social entrepreneurship: How intentions to create a social enterprise are 
formed. Working paper, No 521. Universidad de Navarra, Barcelona: IESE Business School.

Mair, J. and E. Noboa. 2006. Social entrepreneurship: How intentions to create a social venture are formed. Social Entrepreneurship 11(1): 121-135.

Mair, J. and I. Marti. 2006. Social entrepreneurship research: A source of explanation, prediction, and delight. Journal of World Business 41(1): 36-44.

Nel, H. and M. Neale-Shutte. 2013. Examining the evidence: Graduate employability at NMMU. South African Journal of Higher Education 27(2): 437-453.

Nicholls, A. (Ed.). 2006. Social entrepreneurship: New models of sustainable social change. Oxford University Press, Oxford UK.

Nicholls, A. 2011. Editorial: Social enterprise - at the forefront of rethinking business. Journal of Social Entrepreneurship 2(1): 1-6.

Peredo, A. M. and M. McLean. 2006. Social entrepreneurship: A critical review of the concept. Journal of World Business 41(1): 56-65.

Porter, M. and M. Kramer. 2011. The big idea: Creating shared value. Harvard Business Review January/February: 1-17.

Rwigema, H., B. Urban and R. Venter. 2010. Entrepreneurship theory in practice. Oxford University Press, South Africa.

Schlaegel, C. and M. Koenig. 2014. Determinants of entrepreneurial intent: A meta-analytic test and integration of competing models. Entrepreneurship Theory and Practice March: 291-332.

Schurr, J. and A. Newing. 1997. A conceptual and analytical framework for youth enterprise and livelihood skills development: Defining an IDRC Niche. IDRC, Canada.

Seekings, J. 2008. The continuing salience of race: Discrimination and diversity in South Africa. Journal of Contemporary African Studies 26(1): 1-25.

Seelos, C. and J. Mair. 2005. Social entrepreneurship: Creating new business models to serve the poor. Business Horizons 48(3): 241-246.

Shane, S. and S. Venkataraman. 2001. Entrepreneurship as a field of research: A response to Zahra and Dess, Singh and Erickson. Academy of Management Review 26(2): 217-239.

Shapero, A. and L. Sokol. 1982. Social dimensions of entrepreneurship. In Encyclopaedia of Entrepreneurship, ed. C. A. Kent, D. L. Sexton and K. H. Vesper, 72-90. Englewood Cliffs, NJ, Prentice Hall.

Terjesen, S., J. Lepoutre, R. Justo and N. Bosma. 2012. Global entrepreneurship monitor: 2009 report on social entrepreneurship. Santiago: Babson Park, London: Babson College, Universidad del Desarrollo, Global Entrepreneurship Research Association.

Universities SA. 2016. http://www.universitiessa.ac.za/public-universities-south-africa

Urban, B. 2008. Social entrepreneurship in South Africa: Delineating the construct with associated skills. International Journal of Entrepreneurial Behaviour and Research 14(5): 346-364.

Urban, B. 2015. Evaluation of social enterprise outcomes and self-efficacy. International Journal of Social Economics 2(2): 163-178.

Urban, B. and R. Pendame. 2015. Perseverance among university students as an indicator of entrepreneurial intent. South African Journal of Higher Education 29(5): 263-278.

Venter, R. B. 2014. Exploring how values shape the entrepreneurial propensity of youths: A study of the young, black South African entrepreneur. A thesis submitted to the Faculty of Commerce, Law and Management, University of the Witwatersrand, Johannesburg, in fulfilment of the requirements for the degree of Doctor of Philosophy.

Walker, M. 2015. Advancing student well-being and agency: Outline of a 'capabilities-friendly' approach. South African Journal of Higher Education 29(5): 279-296. 